\title{
The Influence of Self-Efficacy on Entrepreneurial Intention among Engineering Students
}

\author{
U. N. Saraih ${ }^{1,}$, Ain Zuraini Zin Aris ${ }^{l}$, Suhana Abdul Mutalib ${ }^{2}$, Tunku Salha Tunku Ahmad ${ }^{1}$, Sharmini Abdullah ${ }^{3}$ and M. \\ Harith Amlus ${ }^{1}$
}

1School of Business Innovation and Technopreneurship, Universiti Malaysia Perlis (UniMAP), Malaysia

2School of Human Development and Technocommunication, Universiti Malaysia Perlis (UniMAP), Malaysia.

${ }_{3}$ Centre of International Language, Universiti Malaysia Perlis (UniMAP), Malaysia.

\begin{abstract}
The objective of this study is to examine the influence of self-efficacy on entrepreneurial intention amongst engineering students from Public Higher Educational Institution (PHEI) in Malaysia. This study employs a quantitative method using the questionnaire instrument. Data is obtained from 345 respondents comprising of final year students from various public institutes of higher learning in Malaysia. Findings revealed that the students from these public institutes demonstrated a high interest in entrepreneurial intention (mean=3.67, $\mathrm{SD}=.54$ ) and a moderate level of sel-efficacy (mean=3.22, $\mathrm{SD}=.71$ ). Findings also pointed out that self-efficacy is significantly associated with entrepreneurial intention $(\beta=.45, \mathrm{p}<.01)$ as exhibited by the engineering students in these institutes. These findings further reinforces an element of Bandura Social Learning Theory which states that self-efficacy is able to influence the entrepreneurial intention amongst engineering students in public institutions. As a result, public instituitions can emphasize strategies to increase the degree of self-efficacy amongst students to enhance the level of entrepreneurial intention. Theoretical and practical implications of the findings are also discussed along with recommendations for the further improvement of institution management.
\end{abstract}

\section{Introduction}

Empirical works reveal that most countries nowadays are facing a surge in unemployment problems. Thus, entrepreneurial knowledge and skills may help the countries to reduce the unemployment problem [1]. According to [2], limited opportunities to gain employment occured mostly in competitive environments. In line with this statement, graduates from universities and colleges also found some difficulties to secure their employment in both public and private sectors due to the current volatile economic environment [3].

In the local context, the Ministry of Higher Education or MoHE tries to switch and focus on entrepreneurship as a gateway to the employment creation in order to stabilize the economies. This initiative is consistent with [4] who stated that the entrepreneurship development could solve unemployment problems.

The discussion on the intentions in entrepreneurship research has attracted the attention of scholars for more than thirty years [5]. As claimed by these authors intentions have recently become a research field which promised to help us better understand the phenomenon of entrepreneurial activity and provided some answers to a basic question in entrepreneurship research such as what makes individuals more entrepreneurial?

Therefore, entrepreneurship education is an important key point to promote entrepreneurship development to the countries' economy. In the Malaysian context, MoHE has taken several initiatives to render entrepreneurship as a compulsory subject to all its educational programs in the public universities. Hence, entrepreneurial disciplines has been introduced as among the most important component to produce students with entrepreneurial minds (National Education Blueprint, Higher Education).

Given that, self-employment as an entrepreneur is a career that must be given attention as an alternative for graduates alongside those employed in facing the volatile limited job market and high retrenchment rate [6]. Hence, an investigation is warranted to reveal the level of entrepreneurial intention among students who are not in the non-economic or in the business programs (eg. engineering students). This is because entrepreneurship can provide an alternative source of income when an economy cannot yet supply enough jobs [7].

\footnotetext{
* Corresponding author: ummi@unimap.edu.my
} 
Based on the MoHE statistics, the unemployment percentage for the first degree graduates from the sub field of technical and engineering are reported at $33.7 \%$ in 2015 [8]; and 33.2\% in 2014 [9]. Thus, it revealed that the percentages of unemployment among graduates in these sub fields seemed high. Therefore, this implied that the current Malaysian students in engineering field have a low to moderate level of intention to become future entrepreneurs. As a result, the researchers attempted to investigate the level of entrepreneurial intention among students from various engineering programs in one public university in Malaysia

However, although self-efficacy has been proven as a predictor to individuals' entrepreneurial intention, there is a lack of evidence that demonstrates the influence of this factor on entrepreneurial intention particularly amongst the Malaysian engineering students. Therefore, this study is aimed to examine the influece of selfefficacy on entrepreneurial intention among the engineering students in the Malaysian context. Should the findings of this study reveal that self-efficacy has the ability to create influences on students' entrepreneurial intention; then appropriate initiatives can be wellplanned to decrease the unemployment percentage among the future engineering graduates in Malaysia, particulary in the aspect of enhancing the level of students' self-efficac

\section{Literature Review}

\subsection{Entrepreneurial Intention}

Entrepreneurial intention has become a popular topic of research. However, only a limited number of studies has focused on the entrepreneurial intention among students [10]. The empirical work of entrepreneurial intentions first began in research of the psychologist Bandura [11, 12] with the introduction to the concept of self-efficacy in the social cognitive theory which is defined as the belief in one's capabilities to organize and execute the courses of action required to manage prospective situations.

Another author [13] define entrepreneurial intention as a commitment to start a new business. Meanwhile, [14] defined entrepreneurial intention as the intention to start a new business. According to [15], the decision to become an entrepreneur and create a new business is a deliberate and conscious decision that requires time, considerable planning and a high degree of cognitive processing.

As stated by [16], entrepreneurial intention describes the degree of commitment directed towards the performance of the entrepreneurial endeavour of putting up a business for self-employment. However, other researchers in China [17] defined entrepreneurial intention as a mental orientation such as desire, wish and hope that can influence their choice of entrepreneurship.
In this study, the researchers attempt to examine the influence of self-efficacy on entrepreneurial intention among the engineering students. According to [11], selfefficacy is a key construct in social learning theory. However, there is a lack of evidence in the local context, particularly regarding the influence of self efficacy on the level of entrepreneurial intention among the Malaysian engineering students. Therefore, this study will contribute some useful insights into this field of study.

\subsection{The Influence of Self-Efficacy on Entrepreneurial Intention}

Self-efficacy is widely recognized as a key construct in social learning theory [11]. Self-efficacy refers to people's judgments regarding their ability to perform a given activity $[11,12,18]$ and is proposed to influence individual choices, goals, emotional reactions, effort, ability to cope, and persistence [19].

As defined by Bandura [12], self-efficacy is the taskspecific consideration of perceived fitness to perform a particular activity. Therefore in the case of entrepreneurship, entrepreneurial self-efficacy may be comprised of deliberation of those tasks that relate to the initiation and development of new ventures. A different approach to clarifying entrepreneurial efficacy is to consider the broader human competencies associated with new venture development.

A study of [10] in Nigeria found that self-efficacy determined entrepreneurial intention of students in tertiary institutions with $\mathrm{R}=.679 ; \quad \mathrm{R} 2=.461 ; \quad \mathrm{F}(2$, $465)=53.007 ; \mathrm{P}<.05$ ). Thus, this confirms a significant prediction of self-efficacy on the tertiary students' entrepreneurial intention in Nigeria. In the United States, a similar relationship between self-efficacy and entrepreneurial intention is presented. These authors [20] also revealed a positive correlation between self-efficacy and entrepreneurial intention among students who took the introductory to entrepreneurship course. This similar pattern of relationship is supported by [21] who conducted a study on entrepreneurial intention among 215 new undergraduate students in one reputable university in Indonesia. These authors presented that self-efficacy has a positive and significant influence on entrepreneurial intention.

Meanwhile, a study of [5] on entrepreneurial intention in Poland found that the level of entrepreneurial intentions is gender-dependent and men had higher intentions towards venture creation than women. However, self-efficacy is not a major factor in shaping entrepreneurial intentions in this study. This is because the reason for lower entrepreneurial intention among women in this study is not significantly connected with their self-efficacy. 
Martinez Campo in [22] investigated the mediating role of gender in the relationship between self-efficacy and the development of individual intentions to become entrepreneurs in a group of people in BarranquillaColombia. They focused on the influence of self-efficacy entrepreneurial intentions by using gender as a mediator. However, the results do not provide evidence to consider gender as a mediator in the relationship between selfefficacy and the development of individual intentions to become entrepreneurs.

Entrepreneurial self-efficacy is viewed as having the capabilities that can modify a person's belief in his or her likelihood of completing the tasks required to successfully initiate and establish a new business [18]. In this study, the views of entrepreneurial intention are obtained from the formulation of self-efficacy among the Malaysian engineering students.

Given the above literature, specific hypotheses are developed as follows:

$\mathrm{H}_{1}$ : There is a moderate level of entrepreneurial intention among the engineering students in this institution.

$\mathrm{H}_{2}$ : There is a moderate level of self-efficacy among the engineering students in this institution.

$\mathrm{H}_{3}$ : There is a significant relationship between selfefficacy and entrepreneurial intention in this institution.

\section{Methodology}

This study involved a sample of the engineering students from one of PHEI located in the Northern Region of Malaysia. The Questionnaire Set consisted of three (3) sections: Section A (entrepreneurial intention), B (selfefficacy) and C (demographic). Likert scales are commonly used to measure attitude, providing a range of responses to a given question or statement. In this study, the scale for entrepreneurial intention and self-efficacy ranged from (1) strongly disagree to (5) strongly agree.

The adapted instruments used for this study has been presented in Table 1.

Table 1. Instrumentation for Variables

\begin{tabular}{|l|c|c|}
\hline \multicolumn{1}{|c|}{ Variables } & No of Items & Authors \\
\hline Entrepreneurial Intention & 9 & {$[23]$} \\
\hline Self-efficacy & 8 & {$[24]$} \\
\hline
\end{tabular}

The 9 items of [23] which have been asked for entrepreneurial intention in this study are: I will choose a career as an entrepreneur; I will choose a career as an employee in a companylan organization; I prefer to be an entrepreneur rather than to be an employee in a companylan organization; The idea is appealing of one day starting your own business; I would rather found/form a company than to be a manager of an existing one; I want the freedom to express myself in my own business; I would rather be my own boss than have a secure job; I enjoy the challenge of creating a new business; and You can only make big money if you are self-employed.

Whereas, the 8 items of [24] which have been used to obtain the information on students' self-efficacy are: I will be able to achieve most of the goals that I have set formyself; When facing difficult tasks, I am certain that I will accomplish them; In general, I think that I can obtain outcomes that are important to me; I believe I can succeed at most any endeavor to which I set my mind; I will be able to successfully overcome many challenges; I am confident that I can perform effectively on many different tasks; Compared to other people, I can do most tasks very well; and Even when things are tough, I can perform quite well.

Results of pilot test presented that the Cronbach alpha values for entrepreneurial intention and selfefficacy are reported at 0.68 and 0.88 each. Generally, the acceptable reliability lower limit value of Cronbach's Alpha should be more than .70. However, Cronbach's Alpha of .60 could also be accepted as stated by [25]. Thus, these suggest that the specified indicators are acceptable to be used for further analysis.

\section{Results and Discussions}

Out of 500 distributed questionnaires, only 345 could be used for further analysis. With reference to gender composition based on the Questionnaire Set, the respondents were made up of 136 males $(39.4 \%)$ and 209 females $(60.6 \%)$. 223 participants $(64.6 \%)$ are Malays, 91 participants $(26.4 \%)$ are Chinese, 10 participants $(2.9 \%)$ are Indians and the remaining 21 participants $(6.1 \%)$ represents other races. Hence, the subjects came from the three main ethnic groups of the Malaysian populations; namely, Malay, Chinese and Indian.

Results represents that over than $3 / 4$ of the participants $(83.5 \%)$ are in the range of 21 to 23 years old. Next, there are $15.9 \%$ of the participants come in the range of 24 to 26 years old. Apart from that, $.3 \%$ of participants are in the group of 27 to 29 years old. The remaining $.3 \%$ comes from the category of above than 30 years old.

With regards the schools categories, the participants came from the various types of schools/faculties. The majority of respondents came from School of Engineering Technology which contributed about $42.0 \%$. This figure is followed by respondents from School of Computer and Communication Engineering (35.4\%), School of Manufacturing Engineering (21.2\%) and School of Mechatronics Engineering (1.2\%). The small percentage of the respondents which contributed of $.3 \%$ came from School of Microelectronics Engineering.

In the aspect of family business background, more than half of the participants $(65.8 \%)$ stated that they came from families that have a business background. 


\subsection{Mean and SD Analyses}

Table 2 presents the means for all variables which are relatively high, with the means for all variables exceeding the scale mid-point of three. In this study, the interpretation of mean scores have been interpreted in the ranged of low (1.00-1.66), moderate (1.67-3.33) and high (3.34-5.00). Based on the results, it is noted that the mean for entrepreneurial intention is high at 3.67. Therefore, $\mathrm{H}_{1}$ is not supported in this study. In the perspective of predictor, the means is noted as moderate which is 3.22 for self-efficacy. Thus, it can be confirmed that respondents in this study have a moderate level of self efficacy. Therefore, $\mathrm{H}_{2}$ is supported in this study.

Table 2. Mean and SD Values

\begin{tabular}{|l|c|c|c|}
\hline Variables & $\mathrm{N}$ & Mean & $\mathrm{SD}$ \\
\hline $\begin{array}{l}\text { Entrepreneurial } \\
\text { Intention }\end{array}$ & 345 & 3.67 & .54 \\
\hline Self-efficacy & 345 & 3.22 & .71 \\
\hline
\end{tabular}

The SD values for entrepreneurial intention and selfefficacy are reported at .54 and .71 respectively. These low levels of all SD values demonstrated that most respondents were close to the mean for both variables in this study.

\subsection{Correlation Analysis}

A correlation analysis was performed to assess the strength and direction of a linear relationship between the variables of the study. The correlation coefficients indicate the strength and the direction between two variables. The closer the coefficient is to either -1.0 or + 1.0 , the stronger the correlation between the variables. This analysis was conducted on both variables in this study, which are entrepreneurial intention and selfefficacy. In interpreting the strength of relationships between variables, the correlation coefficient is as follow:

Very high correlation ( 0.90 to 1.00$)$, high correlation ( 0.70 to 0.89 ), moderate correlation ( 0.40 to 0.69$)$, low correlation ( 0.20 to 0.39$)$ and very low correlation $(0.00$ to 0.19). As shown in Table 2, entrepreneurial intention are moderately correlated with self-efficacy $(\mathrm{r}=.45$, $\mathrm{p}<.01)$.

Table 2. Correlation Analysis

\begin{tabular}{|l|c|c|c|}
\hline Variables & $\mathrm{N}$ & 1 & 2 \\
\hline $\begin{array}{l}\text { Entrepreneurial } \\
\text { Intention }\end{array}$ & 345 & - & \\
\hline Self-efficacy & 345 & .45 & - \\
\hline
\end{tabular}

\subsection{Regression Analysis}

As shown in Table 3, 20.0\% of the variance in entrepreneurial intention is explained by self-efficacy $(\mathrm{R} 2=.20)$

Table 3. Regression Analysis

\begin{tabular}{|l|c|c|c|c|}
\hline Variables & \multicolumn{4}{|c|}{ Entrepreneurial Intention } \\
\hline & Beta & Sig. & $\mathrm{R}^{2}$ & $\begin{array}{c}\text { Adjusted } \\
\mathrm{R}^{2}\end{array}$ \\
\hline $\begin{array}{l}\text { Self- } \\
\text { efficacy }\end{array}$ & .45 & .00 & .20 & .20 \\
$* *$ Correlation is significant at the 0.01 level (2-tailed)
\end{tabular}

The remaining of $80.0 \%$ of variance in entrepreneurial intention among these engineering students is explained by the other variables. In addition, the adjusted $\mathrm{R}^{2}$ value also taken into account as .20 . Based on the results, entrepreneurial intention is positively associated with self-efficacy $(\beta=.45, \mathrm{p}<.01)$.

Thus, this implied that self-efficacy is significantly related with entrepreneurial intention amongst the engineering students in this institution. Therefore, $\mathrm{H}_{3}$ is supported in this study

\section{Conclusion}

The results of this study provided new knowledge regarding the level of students' entrepreneurial intention as well as self-efficacy amongst the engineering students in one of the PHEI in Malaysia. Based on the findings, it is presented that the level of entrepreneurial intention is high in this institution with the mean score at 3.67. However, the result on self-efficacy revealed that there is a moderate level of this variable among the engineering students in this institution with the mean score of only 3.22. This study also revealed that students' self-efficacy are positively and significantly correlated to entrepreneurial intention $\quad(\mathrm{r}=.45, \quad \mathrm{p}<.01)$.

Therefore, by identifying students' strengths as well as their weaknesses especially on the factors of selfefficacy towards entrepreneurial intention, it provides a clearer career path for these students. Hence, the institutions are able to identify from what angle they can increase the level of students' self-efficacy that in turn will help shape the students' intention towards determining their own employment career.

According to [18], education serves as a preparatory function in relation to new venture creation, transferring of knowledge and the relevant skills that increase the selfefficacy. Therefore, self-efficacy will predict the effectiveness of the future entrepreneurs. The author also presented that perceived self-efficacy concerns with the judgments of how well a person can execute a specific action to deal with certain situations [12]. In this study, the institution needs to boost the elements of students' self-efficacy. Only then can these students demonstrate 
specific actions to deal with certain situations as future entrepreneurs.

Previous research indicated that student levels of entrepreneurial self-efficacy are high, thus, the tendency to become an entrepreneur is also high [26]. Although the level of self-efficacy is moderate in this study, however early aspirations towards entrepreneurship can be formed at the first year of students at the tertiary level.

As stated by [27] intention is a function of perceived selfefficacy, which also means the control over behavior. Thus, other authors [28] claimed that self-efficacy and perceived behavioral control are used interchangeably since the concept of perceived behavioral control is closely related to self-efficacy. Meanwhile, [29] claimed that perceived behavioural control is the same construct as self-efficacy.

The results of this study is consistent with the previous research $[10,20,28]$ of who presented that selfefficacy and entrepreneurial intention is positively associated. However, the findings of this study is inconsistent with the previous research $[30,31]$ who argued that selfefficacy does not have significant direct effect towards entrepreneurial intention. For example, as stated by [30] when individuals have a high selfefficacy, this will increase their commitment towards entrepreneurship and lead to greater motivation to start a business.

This research has been conducted in other foreign countries. It may be different with the Malaysian context,as students also possess different types of the sociological factors such as personal characteristics, educational program background and family background. Not only do students in this institution have different cultures but the differing environments also play a contributing factor to form the domain of entrepreneurial intention in themselves

\section{References}

1. Iqbal, A., Melhem, Y. \& Kokash, H. Readiness of the university students towards entrepreneurship in Saudi Private University: An exploratory study. European Scientific Journal, 8 (15), 109-131 (2012)

2. Keat, O.Y., Selvarajah, C. \& Meyer, D. Inclination towards entrepreneurship among university students: An empirical study of Malaysian university students. International Journal of Business and Social Science, 2(4), 206-220 (2011)

3. Teshome, T. Attitudes of private higher education students towards entrepreneurship: A case of distance learners in Wolaita Sodo and Hossana Towns. MiddleEast Journal of Scientific Research, 19(2), 277-285 (2014)

4. Dilanchiev,
entrepreneurship A.Relationship between and unemployment: The Case of Georgia. Journal of Social Sciences, 3(2), 5-9, (2014)

5. Kurczeska, A. \& J. Bialek, Is the interplay between self-efficacy and entrepreneurial intention genderdependent?, Argumenta Oeconomica, 2(33), 23-38(2014)

6. Mazdan, A. A. Involvement of graduates in the field of entrepreneurship in Kuala Lumpur, Malaysia. International Journal of Liberal Arts and Social Science, 3(9), 46-53 (2015)

7. Kelly, D.J., Bosma, N. \& Amoros, J.E. Global Entrepreneurship Monitor (GEM) (2010)

8. Ministry of Higher Education (MoHE). "Laporan kajian pengesanan graduan 2015" Retrieved from: http:/graduan.mohe.gov.my/skpgreport/Penerbitan/ SKPG\%202015/6)\%20Bab\%203\% 20\%20Status\%20Pekerjaan\%20Graduan\%202015.pdf (2015)

9. Ministry of Higher Education (MoHE). "Laporan kajian pengesanan graduan 2014" Retrieved from: http:/graduan.mohe.gov.my/skpgreport/Penerbitan/ SKPG\%202014/6)\%20Bab\%203\% 20\%20Status\%20Pekerjaan\%20Graduan\%202014.pdf (2014)

10. Iro-Idoro, C.B. \& Iro-Idoro, E.U. Self-Efficacy as correlates of entrepreneurial intention of tertiary institution students in Ogun State, Nigeria. Self, 5(2) (2015)

11. Bandura, A. Self-efficacy: Toward a unifying theory of behavioral change. Psychological Review, 84, 191- 215 (1977).

12. Bandura, A. Self-efficacy mechanism in human agency. American Psychologist, 37, 122-147 (1982).

13. Krueger, N.F. The impact of prior entrepreneurial exposure on perceptions and new venture feasibility and desirability. Entrepreneurship Theory and Practice, 18, 5-21 (1993)

14. Pillis, E. \& Reardon, K.K. The influence of personality traits and persuasive messages on entrepreneurial intention: A cross-cultural comparison. Career Development International, 12(4), (2007)

15. Wilson, F., Kickul, J. \& Marlino, D. Gender, entrepreneurial self-efficacy, and entrepreneurial career intentions: Implications for entrepreneurship education. Entrepreneurship Theory \& Practice, 31(3), 387-406, (2007)

16. Souitaris, V., Zerbinati, S. \& Al-Laham, A. Do entrepreneurship programmes raise entrepreneurial intention of science and engineering students? The effect of learning, inspiration and resources. Journal of Business Venturing, 22(4), 566-591, (2007)

17. Peng, Z., Lu, G. \& Kang, H. Entrepreneurial intentions and its influencing factors: A survey of the University Students in Xi'an China. Creative Education, 3, 95- 100 (2012) 
18. Bandura, A. Social foundations of thought and action: A social cognitive. Englewood Cliffs, NJ: Prentice Hall. (1986).

19. Gist, M.E., Stevens, C.K. \& Bavetta, A.G. Effects of self-efficacy and post-training intervention on the acquisition and maintenance of complex interpersonal skill. Personnel Psychology, 44, 837861, (1991)

20. Shinnar, R.S., Hsu, D.K. \& Powell, B.C. Selfefficacy, entrepreneurial intentions, and gender: Assessing the impact of entrepreneurship education longitudinally, The International Journal of Management Education, 12(3), 561-570, (2014)

21. Rachmawan, A., Lizar, A.A. \& Mangundjaya, W.L. The role of parent's influence and self-efficacy on entrepreneurial intention. The Journal of Developing Areas, 49(3), 417-430, (2015)

22. Martínez Campo, J.L. Analysis of the influence of self-efficacy on entrepreneurial intentions. Prospect, 9(2), 14-21, (2011)

23. Indari \& Kristiansen. Empirical studies of selfemployment. Journal of Economic Survey, 13, 381- 415 (2003)

24. Chen, G., Gully, S.M. \& Eden, D. Validation of a new general self-efficacy scale, Organizational Research Methods 2001, 4(1), 62-83, (2001).

25. Hair, J.F. Jr., Anderson, R.E., Tatham, R.L. \& Black, W.C. Multivariate data analysis (5th ed.). New Jersey: Prentice Hall (1998)
26. Wan Nur Azlina, I., Ab Rahim, B., Soaib, A., Shamsiah, M. \& Noor Syamilah, Z. Impact of Entrepreneurship Education on the Entrepreneurial Intentions of Students in Technical and Vocational Education and Training Institutions (TVET) In Malaysia, International Education Studies, 8(12), 141- 156 (2015)

27. Liñán, F., Rodríguez-cohard, J.C. \& Ruedacantuche, J.M. Factors affecting entrepreneurial intention levels. 45th Congress of the European Regional Science Association, Amsterdam (2005).

28. Zaidatol, Akmaliah \& Lope Pihie. Entrepreneurship as a career choice: An analysis of entrepreneurial selfefficacy and intention of University students. European Journal of Social Sciences, 9(2), 338-349 (2009)

29. Schwarz, E., Wdowiak, M. \& Breitenecker, R. The effects of attitudes and perceived environment conditions on students' entrepreneurial intent: An Austrian perspective. Education Training, 51(4), 272-291 (2009)

30. Elfving, J., Brännback, M. \& Carsrud, A. Toward a contextual model of entrepreneurial intentions. International Studies in Entrepreneurship, 24(1), 2333 (2009)

31. Paço, A.M.F., Ferreira J.M., Raposo, M., Rodrigues, R.G. \& Dinis, A. Behaviours and entrepreneurial intention: Empirical findings about secondary students. Journal of International Entrepreneurship, 9(1), 20-38 (2011) 